\title{
Information and Telecommunication Technologies in Ensuring the Right to Use the Native Language in the Digital Economy

\author{
${ }^{1}$ Damir Kh. Valeev, ${ }^{2}$ Anas G. Nuriev \\ ${ }_{1,2}$ Kazan Federal University \\ Email: valeev55@gmail.com,anasnuriev@yandex.ru
}

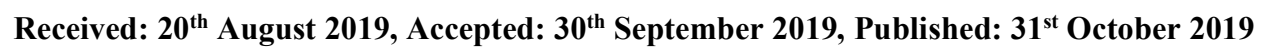

\begin{abstract}
In all four forms of administration of justice (constitutional; civil; administrative; criminal proceedings) for participants in procedural relations, it is possible to: use the native language, as well as use the services of an interpreter. However, the practice of implementing the constitutional right to judicial protection in the context of "language guarantees" is sometimes unreasonably limited due to the infrastructural impossibility of representing a translator. This situation can be easily overcome in the information society, which is a society that provides broad functionality for participants in legal proceedings by creating infrastructural capabilities that can provide public services, since it is the state that can ensure strict observance of the guarantees established in Art. 2 of the Constitution of the Russian Federation by creating a digital infrastructure capable of quickly accessing translation from all languages of the world in all courts of the Russian Federation, regardless of the location of the court. This feature is currently not implemented. This article deals with the potential of the digital economy in resolving these infrastructure problems in order to ensure access to justice.
\end{abstract}

Keywords

Digital Economy; e-Justice; Information Society; Right to Judicial Protection; The Right to Use One's Native Language.

\section{Introduction}

The lack of research on information technologies that can provide "language guarantees" in the administration of justice, the practice of introducing advanced technologies in ensuring the right to use the mother tongue in the judicial system create difficulties in making managerial decisions aimed at the growth and development of the use of information and communication technologies in the judiciary sphere.

It seems that the creation of a concept, initially at the doctrinal level, aimed at developing methodological tools for diagnosing risks and prognostic development trends, in order to uncover the potential of information and telecommunication technologies in ensuring the implementation of the constitutional right to use the native language in litigation in the digital economy, is required. This will help to track the integration of individual electronic technologies in the judicial system of the Russian Federation.

The study of the applied aspects of the implementation of information and telecommunication technologies in legal proceedings in the context of the digital economy seems very important from the point of view of creating "control points" for measuring the actual use of the capabilities of digital technologies so that they entail the achievement of a certain legal result for participants in procedural relations $[1,2,3,4,5]$.

\section{Methods}

The methodological basis of the study was the general provisions of the procedural sciences: constitutional law, civil procedural law, administrative procedural law, criminal procedural law. In the study, the following methods of scientific knowledge were used: interdisciplinary, dialectical, sociological method. The presented study also reflects the intersystem interaction of various fields of knowledge.

\section{Results}

As a result of the study, monitoring of the existing law enforcement practice was carried out in terms of the implementation of the opportunity: 1) to use the native language; 2) using the services of a translator. An attempt has been made to predict the development of the judicial system and improve the regulatory framework taking into account the use of digital technologies aimed at improving language guarantees in the process branches of law.

\section{Discussion}

Decree of the President of the Russian Federation dated 09.05.2017 No. 203 approved the development strategy of the information society in the Russian Federation for 2017-2030 [6], which defines the goals and objectives in the field of application of information and communication technologies aimed at the development of the information society. Moreover, under the information society, a strategy refers to a society in which information and the level of its application and accessibility fundamentally affect the economic and sociocultural living conditions of citizens. The strategy states that information and communication technologies have become part of modern management systems in all sectors of the economy, in the fields of public administration, national defense, state security and law 
enforcement. Effective development of markets and industries (fields of activity) in the digital economy is possible only if there are developed platforms, technologies, institutional and infrastructure environments. In the framework of the effective development of areas of activity, the information infrastructure is important, which allows creating additional guarantees regarding the organization of a situational monitoring and management center for the storage and data processing infrastructure.

Realization of the possibilities of information and telecommunication technologies through the creation of an infrastructure center in the field of providing "language guarantees" will enable the implementation of the constitutional right to judicial protection of persons who do not speak the language of legal proceedings to a qualitatively new level. In a digital economy, digital data becomes a key factor in development, respectively, this ensures equal access for all participants in legal proceedings, regardless of the territorial location of the court, to the possibility of obtaining the right to judicial protection in any language, as established by Art. 26 of the Constitution of the Russian Federation. So, currently in the procedural legislation there is no single approach to the implementation of "language" guarantees.

According to Article 33 (the language of constitutional proceedings) of the Federal Law on the Constitutional Court of the Russian Federation [7], proceedings before the Constitutional Court of the Russian Federation are conducted in Russian. Participants in the process who do not speak Russian are guaranteed the right to provide explanations in another language and use the services of an interpreter.

In accordance with Art. 9 (language of civil proceedings) Code of Civil Procedure of the Russian Federation [8] civil proceedings are conducted in Russian - the state language of the Russian Federation or in the state language of the republic, which is part of the Russian Federation and in whose territory the relevant court is located. In military courts, civil proceedings are conducted in Russian. Persons participating in the case and not knowing the language of the civil proceedings shall be explained and guaranteed the right to give explanations, opinions, make statements, petitions, lodge complaints in their native language, and also use the services of an interpreter.

Based on the provisions of Article 12 (the language in which administrative proceedings are conducted), CAS RF [9] administrative proceedings are conducted in Russian - the state language of the Russian Federation. Administrative proceedings in federal courts of general jurisdiction located on the territory of a republic that is part of the Russian Federation may also be conducted in the state language of that republic. Persons participating in the case and not knowing the language of the administrative proceedings are explained and guaranteed the right to familiarize themselves with the materials of the administrative case, file petitions and lodge complaints in their native language, use the services of an interpreter. In this case, the court decision is set forth in Russian, and at the request of the parties it is translated into the language used during the trial.

As follows from the content of Article 18 (the language of criminal proceedings) of the Code of Criminal Procedure [10], criminal proceedings are conducted in Russian, as well as in the state languages of the republics of the Russian Federation. Participants in criminal proceedings who do not speak or have insufficient knowledge of the language in which the criminal proceedings are conducted should be explained and secured the right to make statements, give explanations and testimonies in their native language, and also use the help of an interpreter free of charge.

In all four forms of administration of justice, it is possible: 1) to use the mother tongue; 2) using the services of a translator. However, the established "normative certainty" has nothing to do with the "actual reality" expressed in the fact that the ability to use the mother tongue and use the services of an interpreter declared in a large settlement will not match the level of its guarantee with the request of a participant in a process declared in another geographical terrain. This can lead to a delay in the process or to a violation of the rights established by Art. 26 of the Constitution of the Russian Federation (language guarantees) and Art. 19 of the Constitution of the Russian Federation (equality of all before the law and the court). This situation can be easily overcome in the information society, which is a society that provides equal opportunities for participants in legal proceedings through the creation of a judicial translation center that can provide public services, since it is the state that can ensure strict observance of the guarantees established in Art. 2 of the Constitution of the Russian Federation by creating a digital infrastructure that can quickly implement:

1. Access to translation from all languages of the world in all courts of the Russian Federation, regardless of the location of the court;

2. Access to professional translation, which will be guaranteed once and for all, will solve the problem of the need for sworn translators.

3. Data in digital form will allow the court to promptly send requests and gain similar access to the results of the operations of the center for court transfers.

Currently, compensation for the cost of implementing this function is regulated in detail by Decree of the Government of the Russian Federation dated 12.01.2012 No. 1240 "On the procedure and amount of reimbursement of procedural costs associated with criminal proceedings, costs associated with the consideration of the case by the arbitration court, civil case, administrative case" , as well as expenses in connection with the fulfillment of the requirements of the Constitutional Court of the Russian Federation and on the recognition of certain acts of the Council of Ministers of the RSFSR and the Government of the Russian Federation as invalid Federation" [11]. However, in law enforcement practice, a lot of questions are caused by the process of choosing a translator and checking the level of his professional training. One can only meet an indirect assessment of the competence of a 
translator in the Code of Criminal Procedure of the Russian Federation. According to Part 2 of Art. 69 of the Code of Criminal Procedure of the Russian Federation, a challenge to a translator can be declared by the parties, and in case of incompetence of a translator, also by a witness, expert or specialist. However, the criteria of incompetence are not specified in the criminal procedure law. In all other procedural sources, an interpreter may be challenged on general procedural grounds.

Thus, the doctrinal study of the possibilities of information and telecommunication technologies, based on the fact that digital data can transform existing social relations and change the way of existing procedural relations in the context of implementing "language" guarantees, is very relevant and can be a "growth point" for the implementation of constitutional judicial protection rights in a digital economy.

\section{Conclusions}

Within the framework of all forms of administration of justice, it is required to create elements of a digital infrastructure that can be quickly implemented: access to translation from all languages of the world in all courts of the Russian Federation, regardless of the location of the court; access to professional translation, which will be guaranteed once and for all, will solve the problem of the need for sworn translators. At the same time, the data in digital form will allow the court to promptly send inquiries and gain similar access to the result of the activity of the digital infrastructure element.

\section{Acknowledgements}

The work is performed according to the Russian Government Program of Competitive Growth of Kazan Federal University.

The reported study was funded by RFBR according to the research project No. 18-29-16147 mk.

\section{References}

1. Damir Kh. Valeev, Anas G. Nuriev., Rafael V. Shakirjanov. Implementation of the constitutional right to judicial protection in the state languages of the subject of the Russian Federation// Revista Dilemas Contemporáneos: Educación, Política y Valores. - Year: VI. -Núm: Special Edition. - Article no.: 24. - Period: December 2018.

2. Nuriev A.G., Khodzhiev A.R, Procedural guarantees of rights of citizens of the Russian federation in the foreign states//Research Journal of Applied Sciences. - 2015. - Vol.10, Is.12. - P.832-834.

3. Safin Z.F. Legal Issues Supporting Production and Distribution of Biotech Products / E. V. Luneva, Z. F. Safin // International journal of Advanced biotechnology and Research. - 2016. - Vol. 7. - № 4. - P. 1260-1264.

4. Valeev D.K., Golubtzov V.G. Modernization of the Russian law: a review of the laws on enforcement proceedings // Life Science Journal. 2014. №11(8s). P. 234-238.

5. Anas G. Nuriev. Characteristics of the Civil liability of the notary / / Revista Dilemas Contemporáneos: Educación, Política y Valores. - Year: VI. - Number: Special Edition. - Item no.: 31. - Period: December 2018.

6. Decree of the President of the Russian Federation dated 05.09.2017 No. 203 "On approval of the Strategy for the development of the information society in the Russian Federation for 2017 - 2030" // FL of the Russian Federation. - 05/15/2017. No. 20. Art. 2901.

7. Federal constitutional law of July 21, 1994 No. 1-FKZ "On the Constitutional Court of the Russian Federation" // FL of the Russian Federation of July 25, 1994. No. 13. Art. 1447.

8. The Civil Procedure Code of the Russian Federation of November 14, 1992 // FL of the Russian Federation. dated November 18, 2002. - No. 46.- Art. 4532

9. Code of Administrative Procedure of the Russian Federation of March 08, 2015 // FL of the Russian Federation. - dated March 9, 2015. - No. 10. - Art. - 1391.

10. The Code of Criminal Procedure of the Russian Federation of December 18, $2001 / /$ FL of the Russian Federation. - dated December 24, 2001 - No. 52 (part one). - Art. - 4921.

11. Decree of the Government of the Russian Federation of 01.12.2012 No. 1240 "On the procedure and amount of reimbursement of procedural costs associated with criminal proceedings, costs in connection with the consideration of the case by the arbitral tribunal, civil case, administrative case, as well as expenses related to the fulfillment of the requirements Of the Constitutional Court of the Russian Federation and on the recognition as invalid of certain acts of the Council of Ministers of the RSFSR and the Government of the Russian Federation" // FL of the Russian Federation dated 10.12.2012. No. 50 (part 6). Art. 7058. 